\title{
On the Lack of True Philosophic Spirit in Aquinas
}

Mark Nelson ${ }^{1}$ cites Russell ${ }^{2}$ on Aquinas:

There is little of the true philosophic spirit in Aquinas. He does not, like the Platonic Socrates, set out to follow wherever the argument may lead. He is not engaged in an inquiry, the result of which it is impossible to know in advance. Before he begins to philosophise, he already knows the truth; it is declared in the Catholic faith. If he can find apparently rational arguments for some parts of the faith, so much the better; if he cannot, he need only fall back on revelation. The finding of arguments for a conclusion given in advance is not philosophy, but special pleading. I cannot therefore, feel that he deserves to be put on a level with the best philosophers either of Greek or of modern times.

He then goes on to claim that "like many of Russell's pronouncements, this is breathtakingly supercilious and unfair”. Later, he adds that Russell’s “dismissal” of Aquinas is "sniffy" 3 .

I think that there is probably about as much justice in the claim that it is Nelson himself who is "breathtakingly supercilious and unfair"—and "dismissive" and "sniffy"-in his treatment of this passage from Russell. While it is unclear how far one ought to agree with Russell's assessment of Aquinas' standing as a philosopherand while it is not entirely clear exactly what grounds Russell has for the assessment which he makes-I think that a good case can be made for the claim that Nelson completely misrepresents the position which Russell develops in the final five 
paragraphs of his chapter on Aquinas. The aim of the present paper is to make this case.

\section{1}

Nelson gives several reasons in support of his claim that what Russell says is unfair to Aquinas:

(1) What Russell says takes no account of the nuanced things which Aquinas actually says about the relation between faith and reason (as, for example, in Summa Contra Gentiles, Book 1, chs.2-12). ${ }^{4}$

(2) Russell fails to adduce a single case in which Aquinas fails to follow an argument where it leads. Moreover, this is not surprising, since Aquinas is actually quite scrupulous in following arguments where they lead (as, for example, in his discussion of the eternity of the world, Summa Theologiae 1a, q.46, a.2). ${ }^{5}$

(3) In Principia Mathematica, Russell himself spends several hundred pages trying to prove that $2+2=4$; yet this is surely something which he believed before he began to philosophise. ${ }^{6}$

(4) Russell's criticism of Aquinas relies upon an epistemic principle (DAM) which is demonstrably wrongheaded, and which Russell himself is elsewhere committed to rejecting. ${ }^{7}$ 
After we have examined the epistemic principle mentioned in (4)—and after we have carefully examined what Russell actually says in the concluding paragraphs of his chapter on Aquinas - we shall return to consider whether any of these reasons gives good grounds for Nelson's verdict.

\section{2}

Nelson formulates the epistemic principle on which Russell's criticism of Aquinas allegedly relies as follows ${ }^{8}$ :

(DAM): Belief B is epistemically permissible for $\mathbf{S}$ at $\mathbf{t}$ iff B has maximal argument value for S at t, where: B has Maximal Argument Value for S at $\mathbf{t}$ iff no incompatible belief has higher overall argument value for $\mathrm{S}$ at $\mathrm{t}$; and the Overall Argument Value of $\mathbf{B}$ for $\mathbf{S}$ at $\mathbf{t}=_{\mathrm{df}}$ the balance of the value of the arguments for belief B over the value of the arguments against B, for S at t; where the Value of an Individual Argument for $\mathbf{B}$ for $\mathbf{S}$ at $\mathbf{t}$ is some function of the degree of justification for $\mathrm{S}$ at t of that argument's premises and the degree of truth-preservingness of the relation between that arguments premises and its conclusion.

Nelson has little trouble in establishing that this principle is unacceptable. I think that there are more reasons to find this principle unacceptable than Nelson gives; I certainly agree with him that it is unacceptable. (Note, in particular, that any argument of the form "P, therefore $\mathrm{P}$ ” will have maximal argument value whenever $\mathrm{P}$ has maximal justification, as will any argument of the form "P\&N, therefore P”, where $\mathrm{N}$ is any other proposition with maximal justification. Plainly, it can’t be right to 
suppose that the value of an argument is merely a matter of the degree of justification of the premises and the degree of truth-preservingness of the relation between the premises and the conclusion. Note, too, that it is plausible to suppose that, for any proposition which does not have an extremal degree of justification, there are infinitely many arguments for that proposition of the form “P\&N, therefore P”, and infinitely many arguments against that proposition of the form “ P\&M therefore $\sim \mathrm{P}$, where the premises have non-zero degree of justification. For instance, there are all the premises of the form $P \&(n+0=n)$, where $n$ is a natural number; and all the premises of the form $\sim P \&(m+0=m)$, where $m$ is a natural number. If we suppose that we are to sum over all the arguments which there are for a given conclusion, then we shall have to worry about delicate issues concerning the addition and subtraction of infinite quantities. The very idea that beliefs have "argument value” is plausibly undermined by these kinds of considerations.)

Nelson also notes reasons for being uneasy about the attribution of this principle to Russell. First, of course, Russell nowhere explicitly endorses any such principle. Second, this principle is inconsistent with much else that Russell does explicitly say: Russell is plainly an epistemic pluralist who acknowledges that perception, memory, logico-semantic intuition, and much else besides, can be sources of permissible beliefs. (And, third, I would add, there are many evident reasons for rejecting (DAM); it is absurd to think that Russell would even implicitly have committed himself to such a stupid epistemological doctrine.)

Nelson's response at this point is twofold. First, he claims that Russell's criticism of Aquinas cannot get off the ground without something like (DAM). ${ }^{9}$ Second, he claims 
that Russell's departure from grace is an example of the tendency of secular philosophers to invoke double-standards when criticising religion: philosophers who ought to know better hold religious beliefs to standards that they would never dream of applying to ordinary beliefs or even to other philosophical theses. ${ }^{10}$

As I remarked above, I think that it is absurd to suppose that Russell ever supposed anything remotely like DAM; in particular, I think that it is a mistake to suppose that Russell's criticism of Aquinas relies on the principle which Nelson enunciates. The crucial question concerns the interpretation of the passage with which we began: what exactly is it that Russell is saying here? Once we have worked this out, we shall be in a position to decide whether the reasons which Nelson gives for claiming that Russell is unfair to Aquinas are good. And, until we have worked this out, we have no idea.

Russell begins his concluding assessment of Aquinas with a statement of what he takes to be considerable virtues:

The originality of Aquinas is shown in his adaptation of Aristotle to Christian dogma, with a minimum of alteration. In his day he was considered a bold innovator; even after his death many of his doctrines were condemned by the universities of Paris and Oxford. He was even more remarkable for systematising than for originality. Even if every one of his doctrines was mistaken, the Summa would remain an imposing intellectual edifice. When he wishes to refute some doctrine, he states it first, often with great force, and almost always with an attempt 
at fairness. The sharpness and clarity with which he distinguishes arguments derived from reason and arguments derived from revelation are admirable. He knows Aristotle well, and understands him thoroughly, which cannot be said of any earlier Catholic philosopher. ${ }^{11}$

So far, not "sniffy", not "breathtakingly supercilious”, and not even "unfair”.

However, Russell continues, these merits—considerable as they are—-"seem scarcely sufficient to justify his immense reputation”. Why not? Well, several different reasons are suggested by what Russell goes on to say in the next few paragraphs. However, the main point seems to be that, for Aquinas — and for Catholics in general—-the arguments which Aquinas gives very often do not give the real or true grounds for their beliefs. Consider, for example, Russell’s discussion of Aquinas on “the indissolubility of marriage”:

This is advocated on the ground that the father is useful in the education of the children (a) because he is more rational than the mother, (b) because, being stronger, he is better able to inflict physical punishment. A modern educator might retort (a) that there is no reason to suppose men in general more rational than women, (b) that the sort of punishment that requires great physical strength is not desirable in education. He might go on to point out that fathers, in the modern world, have scarcely any part in education. But no follower of St Thomas would, on that account, cease to believe in lifelong monogamy, because the real grounds of belief are not those which are alleged. ${ }^{12}$ 
I don't think that it is entirely clear whether the main target here is St. Thomas, or whether it is rather modern followers of St. Thomas. What is clear is that Russell thinks that Aquinas’ arguments are weak, and plainly so. Moreover, he seems to see some kind of connection between the allegedly evident weakness of the arguments and a departure from good epistemic practice on the part of those who endorse the arguments.

As I mentioned above, the core of Russell's complaint seems to be that there is a sense in which the Thomistic project is "insincere": the arguments which are advanced do not coincide with the real reasons why beliefs are maintained. Neither St. Thomas nor his followers would give up any of their conclusions if they could be brought to agree that the arguments advanced thus far were no good; for those conclusions are always far more solidly founded in other grounds, namely, in revealed faith. The real grounds for Thomistic belief in the indissolubility of marriage-or the existence of God, or the divine simplicity, or almost any other doctrine which is discussed in the Summae — are to be found in revelation, in Scripture, and in longstanding tradition. Of course, if the arguments are plainly bad-as Russell supposes that they are- - then this makes matters worse; but the core crime is to engage in activity which brings with it the danger that one will be all too ready to reach out to embrace bad arguments.

When Russell says that "the appeal to reason is, in a sense, insincere, since the conclusion to be reached is fixed in advance”, I take it that part of what he means is just the point which I have been making in the previous paragraph: the real grounds of belief are not those which are alleged. But what are we to make of the explanation of 
the sense of insincerity: that the conclusion to be reached is fixed in advance? I think that what Russell is urging is that, when we do have reasons for our beliefs, we should give those reasons when we try to defend those beliefs, rather than cast around for other things which might be used as premises in arguments to the conclusions we favour. Reasoning and argument move from premises to conclusions: you begin with what you are convinced of, and move from there to your conclusions. To start with your conclusions, and then to cast around for things other than your real reasons for holding those conclusions, is actually a kind of perversion of reasoning, since what you are holding fixed is precisely what is not held fixed in genuine reasoning and argument.

Nelson says: “It can seem wrong-headed, philosophically speaking, to decide what you believe first, and then cast about for arguments to back it up. ... I think this is one of the main reasons for the scandal fixed on religious believers in philosophy these days. It is not simply that arguments for theism are not universally compelling, nor that some arguments against theism are formidable. It is that believers appear disposed to believe even when the arguments are not on their side; hence Russell's sneer that “... no Catholic is likely to abandon belief in God even if he becomes convinced that St. Thomas’ arguments are bad; he will invent other arguments, or take refuge in revelation.” It is this intellectual conduct of religious believers, as much as the intellectual content of their belief, that seems unreasonable and calls theistic belief into question.”13

While Nelson is right that it can seem wrong-headed to decide what you believe first and then cast about for arguments to back it up, he is wrong about the nature of 
Russell’s complaint against this procedure. Assuming that “deciding what you believe” requires that you have grounds or reasons for what you come to believe, the objection is not that you believe without argument (or reason); rather, the objection is that you should not pretend to have grounds or reasons other than those which you actually have. Russell's alleged "sneer” is not about the lack of reasons on the side of the theist - though, of course, Russell did believe independently that the weight of reasons is not on the side of the theist; rather, Russell's complaint is about the lack of courage which leads to apparent insincerity. (Here, I assume that Nelson doesn’t really mean that you can just decide what to believe, without having grounds or reasons; if that is what religious folk do, then there is no reason at all why their socalled "beliefs" should be taken seriously.)

If what I have just argued is correct, then it is clear that Russell's complaint against Aquinas does not depend upon the absurd epistemic principle (DAM). Russell’s allegation is not that religious believers do not have arguments for their beliefs; rather, his allegation is that Thomists (and perhaps other religious believers) do not give the arguments which they ought to give when they argue for their religious beliefs. Moreover, Russell's complaint against Aquinas is that it is a perversion of genuine philosophical enquiry to fail to use one's real reasons when arguing for conclusions which one accepts: it is this failure which constitutes the epistemic crime of "failing to follow the argument where it leads", and which is a kind of "special pleading”. 
Even if I am right about the nature of the allegation which Russell makes against Aquinas — and if I am right that Nelson has failed to grasp the true nature of this allegation-it remains an open question whether Russell's complaint against Aquinas is justified. Is it true that one ought not to do what Russell accuses Aquinas of doing? Is it true that Aquinas does do what Russell accuses him of doing? And is it true that Aquinas ought not to be "put on a level with the best philosophers either of Greece or of modern times” because of the alleged failing which Russell identifies?

These are large questions; I can do no more than gesture at answers to them here. I think that there is some substance in the charge that Aquinas ought not to be put on the same level as Plato, Aristotle, Descartes, Hume and Kant. One reason for this is that, unlike those other great philosophers, Aquinas does not make important original contributions to the foundational areas of philosophy: to logic, to metaphysics, to epistemology, and so forth. Great philosophers make original claims, draw original distinctions, discover original techniques, discern original problems, and so on, in the foundational areas of philosophy. Aquinas is not noted for doing these things.

Moreover, I think that there is some substance to the charge that Aquinas did not make original contributions in foundational areas precisely because of the weakness which Russell discerns, i.e. precisely because of his “failure to follow arguments where they lead”. There are obvious reasons why Aquinas was not likely to hit upon strikingly new philosophical doctrines, techniques, problems, and so forth; if that is 
what we most value in philosophy, then there is an obvious reason why we will not rank Aquinas as highly as some other philosophers.

Of course, it might be said that the above remarks depend upon a particular view about what is most valuable in philosophy. Indeed; I hardly expect that modern Thomists will share my view about what makes for greatness in philosophers! However, I do think that it is worth pointing out that Russell shared the sort of outlook which I have outlined. Given what he took to make for greatness is philosophers, it really should not be surprising that he does not rank Aquinas as highly as some others. (Note, too, that this is not the product of prejudice against religious philosophers. Russell ranks Descartes, Berkeley and Leibniz very highly; and, at least part of his reason for doing this is because of the important original contributions which they make in logic and/or metaphysics and/or epistemology.)

There is much more which might be said about the reasons for thinking that philosophers in "commentary" traditions are not likely to reach the same heights as philosophers who aim to discover what they take to be as yet unknown truths about the fundamental nature of the world. If you think that, to the extent that the fundamental nature of the world can be known at all, such knowledge is already recorded in scripture and in other canonical texts, then it seems very unlikely that you will discover what you take to be important new truths about the fundamental nature of the world. Following the argument where it leads-i.e. following speculative lines of thought from the available data to guesses at the fundamental nature of reality-is not open to those who think that nothing important remains to be discovered about the fundamental nature of reality. 
As I noted in Section 1, Nelson makes four different criticisms of Russell, only the last of which invokes the controversial epistemic principle (DAM). I close with a few brief remarks about the other complaints.

(1). That Aquinas has subtle things to say about the relations between faith and reason is irrelevant to Russell's complaint. For one thing, Russell's complaint has nothing to do with Aquinas' theory about the relations between faith and reason; rather, it concerns the practice which Aquinas adopts. For another thing, it won't do to say that it is an article of faith for Aquinas that very many things are supposed to be knowable in the light of reason. For, while this may help to explain—and perhaps even to excuse- - the procedure which Aquinas adopts, it does nothing at all to contradict the claim that Aquinas ought not to be reckoned amongst the very greatest philosophers. (Remember that Russell is not arguing that Aquinas was not a mighty intellect. The specific claim is that Aquinas is not one of the greatest philosophers.)

(2) That there is a sense in which Aquinas is careful to "follow arguments where they lead” is also irrelevant to Russell's complaint. Russell does not say that Aquinas will accept any old argument for conclusions which he favours. Nor does he say that Aquinas is never content to accept that certain conclusions are only available via revelation. Russell's complaint is that Aquinas entire project aims at finding arguments for conclusions whose real justification lies elsewhere: in that sense, Aquinas almost never follows arguments where they lead. (Ironically, when Aquinas 
concludes that it is impossible to demonstrate that the world is not eternal, the argument which he would then give for the non-eternity of the world-namely, that this is something which is vouchsafed by Scripture-is precisely an argument of the kind of which Russell would approve: at least here we are getting the real grounds for the belief!)

(3) That the complaint which Russell makes against Aquinas can be turned against the author of Principia Mathematica is, I think, plainly mistaken. The aim of the Principia is to show that mathematics can be reduced to logic. Russell believed that this could be done, and set out to show that it could be done. There is nothing in the Principia which suggests that Russell was arguing for claims which he believed on other grounds. (Of course, Russell had independent grounds for believing that 2+2=4; but the point of the proof in Principia is not to justify that belief. Rather, the point of the proof is to show that that mathematical belief can be derived from purely logical premises.)

In sum: Nelson's complaints against Russell are quite without substance. While it is true that Russell's verdict relies on a judgement—about what it really valuable in philosophy—which Nelson may well reject, there is no reason for thinking that Russell's criticism of Aquinas involves some kind of double standard. There is, after all, a perfectly good sense in which Aquinas does not "follow the argument where it leads”: Aquinas does not suppose that it is possible for the kind of philosophy of which Russell approves to discover new, deep and important philosophical truths. For Aquinas, it is not enquiry, but rather scripture and tradition, to which one turns when one wants to know the truth. 
${ }^{1}$ M. T. Nelson, 'On the Lack of 'True Philosophic Spirit' in Aquinas: Commitment v. Tracking in Philosophic Method’, Philosophy 76, No. 296 (April 2001), 283

${ }^{2}$ B. Russell, The History of Western Philosophy (London: Unwin Paperbacks, 1979), 453f.

${ }^{3}$ Op. cit. note 1, 296

${ }^{4}$ Op. cit. note 1,283

${ }^{5}$ Op. cit. note 1,283

${ }^{6}$ Op. cit. note 1, 283f. (Cf. Anthony Kenny, Aquinas on Mind (London: Routledge, 1993) 11f.)

${ }^{7}$ Op. cit. note 1, 295 (and elsewhere)

${ }^{8}$ Op. cit. note 1,288

${ }^{9}$ Op. cit. note 1, 295

${ }^{10}$ Op. cit. note 1,295

${ }^{11}$ Op. cit. note 2, 452

${ }^{12}$ Op. cit. note 2, 453

${ }^{13}$ Op. cit. note 1, 284 